The CLASSICAL QUARTERLY and CLASSICAL REVIEW are the organs of the Classical Association. The QUARTERLY is published in January, April, and October (double number); the REVIEW in February, May, July, September, November, and December.
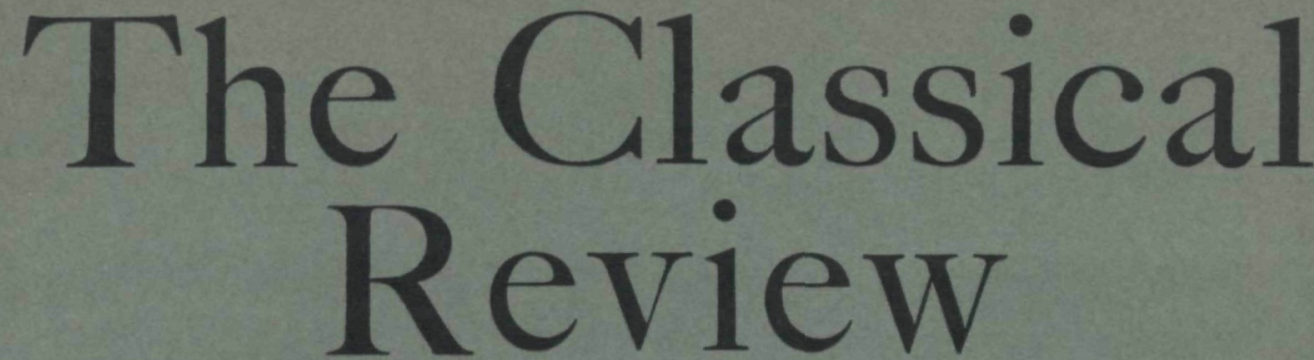

\title{
Editors $\left\{\begin{array}{l}\text { E. HARRISON, M.A., Trinity College, Cambridge } \\ \text { C. J. FORDYCE, M.A., } 3 \text { The University, Glasgow, W. } 2\end{array}\right.$
}

ALL COMBUNICATIONs intended for the Editors should be sent to MR. FORDYCE. BOOKs for review should be sent to the Publisher

\section{BOARD OF MANAGEMENT}

Prof. D. S. ROBERTSON, M.A. (Chairman), representing the Cambridge Philological Saciety J. G. BARRINGTON-WARD, M.A. (Hon. Treas.), Prof. J. F. DOBSON, M.A.,

Prof. H. A. ORMEROD, M.A., F.S.A., F. H. SANDBACH, M.A. (Hon. Sec.)., $\}$ Representing the Council of the Prof. B. H. WARMINGTON, M.A.

E. A. BARBER, M.A., F.B.A., representing the Oxford Philological Society

With the co-operation of

Prof, J. L. MICHIE, University of Queensland, and Pror. E. K. RAND, Harvard University

\section{CONTENTS}

NOTES AND NEWS
THE TRACHINIAE. F. R. EARP
TITUS MACCUS PLAUTUS. W. BEARE
THE EPILOGUE TO THE AGRICOLA. R. G. AUSTIN
EARLY ROMAN COINAGE. J. G. MILNE REVIEWS:

Mythos und Sage bei den Griechen (Radermacher), J. TATE, 118; The Original Iliad (Smith), J. TATE, 119; Euripides, Medea (Page), D. W. LuCAS, 120; Sofocle (Perrotta), T. B. L. Webster, 121; The History of Herodotus (Powell), A. R. W. HARrison, 123; Erodoto, libro nono (Untersteiner), J. E. PowelL, 124; Xénophon, Helléniques, II (Hatzfeld), E. C. Marchant, 125; Heliodori Aethiopica (Colonna), R. M. RATTENBURY, 126; Recherches sur la Chrestomathie de Proclos (Severyns), J. TATE, 128; Forschungen zur Philosophie des Hellenismus (Schmekel), M. Kneale, 129; Plaute, VI (Ernout), W. Beare, 130; Varro, de Lingua Latina (Kent), C. J. ForDYCE, 131; Taciti de Origine et Situ Germanorum (Anderson), E. C. MarCHANT, 132; L. Annaei Flori quae exstant (Malcovati), E. J. Wood, 133; Siliana (Blomgren), J. H. MozLEY, 134; Dated Greek Minuscule Manuscripts, vii-ix (Lake), E. H. MnnNs, 135; Codices Latini Antiquiores, III (Lowe), E. H. MINNs, 135; The History of History, I (Shotwell), A. W. Gomme, 136; Histoire Grecque, IV (Glotz), G. T. GRIFFrTH, 137; Les assemblées de la confédération achaienne; Les premiers rapports de Rome et de la confédération achaienne (Aymard), F. W. WALBANK, 139; The Stranger at the Gate (Haarhoff), A. F. Giles, 140; Apollon (Kerényi), W. K. C. GutHrie, 141; Études d'Archéologie Grecque, B. Ashmole, 142; Excavations at Olynthus, IX (Robinson and Clement), C. H. V. SutherLAND, 143; Greece and the Aegean (Gardner and Casson), In Greece with Pen and Palette (Boyajian), H. D. F. KrrTo, 144; Symbolae Osloenses, XIV-XVIII, E. HARRISON, 145.

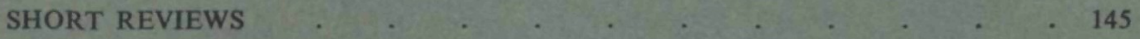

SUMMARIES OF PERIODICALS ..$+ \quad \cdot \quad \cdot \quad \cdot \quad \cdot \quad \cdot \quad \cdot \quad \cdot \quad \cdot 155$

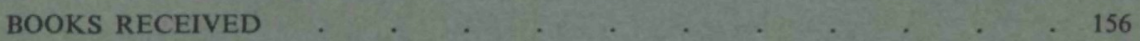

\section{OXFORD : AT THE CLARENDON PRESS}

\section{LONDON, NEW YORK, TORONTO, AND MELBOURNE : HUMPHREY MILFORD}

Price of the present number, 2s. net. Yearly subscription, 12s, net, post free ; U.S.A., S3. Combined yearly subscrip tion for the CLASSICAL QUARTERLY and the CIAISSICAM.REVIEW, 25s. net, post free; U.S.A., \$6.25 


\section{THE}

C L A S S I C A L R E V I E W

EDITED BY

E. HARRISON AND C. J. FORDYCE

BOARD OF MANAGEMENT

PRor. D. S. ROBERTSON, M.A. (Chairman)

J. G. BARRINGTON-WARD, M.A. (Hon. Treasurer)

F. H. SANDBACH, M.A. (Hon. Secretary)

Prot. J. F. DOBSON, M.A.; Prof. H. A. ORMEROD, M.A., F.S.A.

Prof. E. H. WARMINGTON, M.A.; E. A. BARBER, M.A., F.B.A.

With the co-operation of

Pror. J. L. MICHIE, University of Queensland, and

Prof. E. K. RAND, Harvard University

VOLUME LIII

Published in co-operation with the Classical Association OXFORD : AT THE CLARENDON PRESS

LONDON, NEW YORK, TORONTO, AND MELBOURNE : HUMPHREY MILFORD 


\section{TABLE OF CONTENTS}

\section{Number 1}

Notes and news

Plato, Phaedo 92cd. J. TATE

Hades and the pomegranate seed. C. BonNer

Three Pompeian wall-inscriptions, and Petronius. F. A. TODD .

KOIIIATIAE again. J. L. MYRES

Anthol. Pal. X. 73. W. R. INGE .

Reviews:

The Oresteia of Aeschylus (Thomson), G. MURRAY, 10 ; Satyrorum Graecorum Reliquiae (Steffen),A.W. Pickard-Cambridge, I 2; Die METABO^H als Stilprinzip des Thukydides (Ros), J. E. Powell, I3; Das attische Prozessverfahren in seiner Wirkung auf die Gerichtsrede (Lämmli), P. B. R. Forbes, 14 ; The Pythagorean Background of the Theory of Recollection (Cameron), W. K. C. Guthrie, 14 ; Aristotle, Organon I, Categories, On Interpretation, Prior Analytics (Cooke and Tredennick), G. R. G. Mure, 15 ; Etudes plotinienres I (Henry), J. H. Slemuan, I7; $V$ irgil and the Roman Epic (Henry), F. H. Sandbach, 18; Acneas' Arrival in Latium (Boas), F. H. SandBach, 18 ; Pline le Jeure, Panégyrique (Durry), W. S. MAGuInNess, I9; Der Roman des Apuleius(Riefstahl), D.S. RoBerTSON, 20 ; Ad Apulei Metamorphoseon

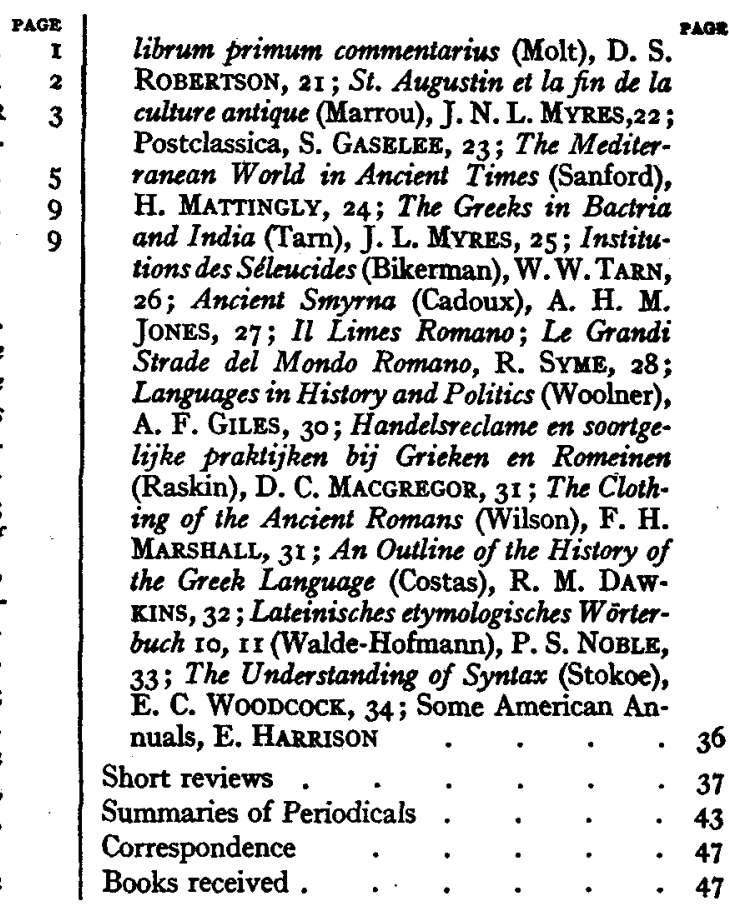

\section{Number 2}

Notes and news

Seats in the Greek and Roman theatres, W. BEARE

Hyperides and the cult of Hephaestion. $\dot{P}$. TREvEs.

The second storm at Artemisium. R. LATTIMORE

TPAXH $\Lambda$ OE 'Head'. J. E. PowELL : .

How Socrates addressed the jury. P. MAAs . Aeschylus, Eum. 430 (433). D. S. RoBERTSON On the MS. E of Aeschylus. E. Fraenkel . Sophocles, O.T. 292 and 566

Reviews:

Early Greek Elegists (Bowra), J. A. DAvisoN, 59; Hippokrates und die Begründung der wissenschafilichen Medizin (Pohlenz), A. L. PeCK, 6r; Der Begriff des Staatsmannes bei Thukydides (Bender), A. W. Gomme, 6I; Menandriquae supersunt, parsprior (Koerte), W. E. MuIR, 62; Papiri della R. Universitd di Milano, I (Vogliano), E. A. BARBER, 63; Suidae Lexicon, IV, V (Adler), H. Stuart Jones, 64; La Poesia di Varrone Reatino (della Corte), J. Wight Durf, 65; Diphilus' doel en deel in de Rudens van Plautus; Two Comediesby Apollodorus of Carystus (Kuiper), H. TREDENNICK, 66 ; Die interpolierte Recension des Terenstextes (Fehl), J. D. Craig, 


\title{
Number 3
}

\author{
Aeneas in Wonderland. J. R. BACON . . . . . $\quad .97$ \\ The Final Scenes of the Phoenissae. H. D. F. KITTO : : $\quad{ }_{104}$ \\ Review:
}

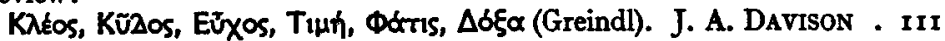

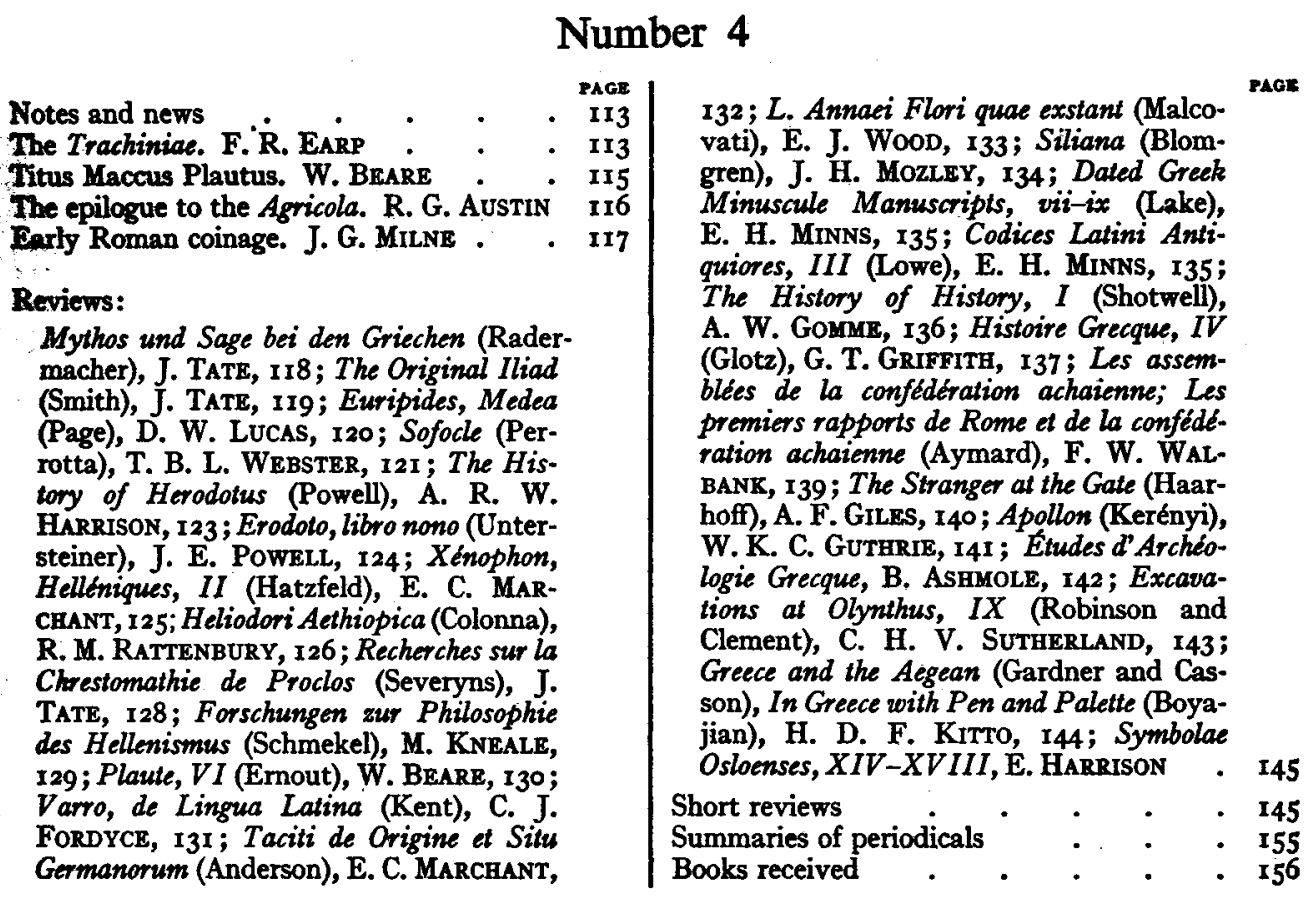

\section{Numbers 5-6}

Notes and news

Notes on the Oresteia. F. M. Cornford

Hercules Furens and Prometheus Vinctus. H. G. Mullens • • • . •

Crepidata, palliata, tabernaria, togata. W. Beare .

Two Pompeian metrical inscriptions F. A. TODD

\section{Reviews:}

The Poetry of Homer (Bassett), G. MURRAY, 170; Greek Art and Literalure, 530-400 B.c. (Webster), H. D. F. KIrro, I72 ; Eschilo, Il Prometeo legato (Rapisarda), G. Tromson, 173; Ion von Chios, die Reste seiner Werke (Blumenthal), A. W. Pickard-CaMbridge, I74; Euripides, Electra (Denniston), A. P. Sinker, 175; The History of the Greek and Roman Theater (Bieber), A. W. PICKard-CAMBRIDGE, 176; Der Staatsmann (Zeise), D. J. ALLAN, 178 ; Aristotle: On the Heavens (Guthrie), D. J. ALLAN, 179; The Literary

$I 61$
162
165
166
168

Treatises of Dionysius of Halicarnassus (Bonner), J. F. Lockwood, 18I ; Plutarchi Vitae Parallelae: Indices (Lindskog and Ziegler), E. HARRISON, 182; Ethica Epicurea (Schmid), C. BarleY, I83; The Adler Papyri (Adler, Tait, Heichelheim, and Griffith), H. I. BELL, 184; The Greek Aulos (Schlesinger), R. P. WinNington-INGRAM, I85; La Letteratura di Roma repubblicana ed augustea (Rostagni), J. WIGHT DUFF, I86; Remains of Old Latin (Warmington), C. J. FORDYCE, 187; The Pattern of Sound in Lucretius (Deutsch), C. BaILEY, 188; Horaz, 1929-1936 (Büchner),L.P. WilkiNson, I9o; Studien zur Ars poetica des Horas (Steidle), J. TAte, 19I ; Pliny, Natural History, I (Rackham), R. G. AUSTIN, 192; Ammianus Marcellinus, III (Rolfe), G. B. A. Fletcher, 193; Le Mythe $d u$ Phénix dans les littératures grecque et latine (Hubaux and Leroy), D'A. W. Thompson, 195; Postclassica, S. Gaselee, 196; The Gateway to the Middle Ages (Duckett), 


\section{Numbers 5-6 (continued)}

R. M. HENRY, 198; Archaische en Archaistische Woordkunst (Westermann), J. W. PIRIE, I99; Principi di sintassi latina: concetto e funzione del modo (Giuffrida), E. C. Woodcock, 200; The Cults of the Sabine Territory (Evans), H. J. RoSE, 201 ; Anatolian Studies presented to William Hepburn Buckler (Calder and Keil), W. K. C. GuthrIE, 202; Saka-Studien (Junge), J. L. MYres, 203; The Stoichedon Style in Greek Inscriptions (Austin), A. M. Woodward, 204; The Cambridge Ancient History, Plates V (Seltman), C. H. V. SUTHERLAND, 206; Early Ionian Historians (Pearson), A. W. Gomme, 207; $A$ Short History of Culture (Lindsay), J. L. MYRES,
PAGE

208 ; Das Wesen der spartanischen Staatsordnung (Meier), V. EHrknberg, 209; Roman Provincial Administration till the Age of the Antonines (Stevenson), E. G. TURNER, $210 ;$ Les distributions de ble et d'argent d la plebe romaine sous l'Empire (van Berchem), R. MEIGGS, 211 ; I bolli laterizi e la storia edilizia romana (Bloch), G. R. C. DAvis, 212; Invloed van het Christendom op de Romeinsche wetgeving betreffende het concubinat en de echischeiding (Jonkers), P. W. Durf, 213; Some Class-Books, D. S. Colman

Short reviews.

Summaries of periodicals . $\quad . \quad$. 226

Books received . . . . . . 229 